DOI: 10.22363/2312-9182-2019-23-2-362-382

\title{
Intertextuality as Translation Problem: Explicitness, Recognisability and the Case of "Literatures of Smaller Nations"
}

\author{
Marta Kaźmierczak \\ University of Warsaw \\ 26/28 Krakowskie Przedmieście, Warsaw 00-927, Poland
}

\begin{abstract}
The paper focuses on the issue of translation of intertextual markers in literature, with a special emphasis on Polish poetry in English renditions. The material and perspective are chosen with a view to exploring source-culture references in the literatures less known internationally, which, it is argued, is a sphere of particular cultural resistance to translation. The aim is to survey the importance of the level of explicitness of intertextual links for the task of a translator, but also to investigate recognisability - the other crucial factor - as well the interrelation of the two. First some assumptions about the conditions conducive to a successful rendering of intertextuality are formulated and tested. Then, based on several poetry excerpts, it is shown how, on the one hand, the level of explicitness influences the translators' choices and, on the other, how explicitating or implicitating procedures in translation influence the interpretative potential of the texts. Some instances of overcoming the resistance thanks to creative efforts are indicated. One of the author's tenets is that even a not readily decipherable marker can serve as a signal of intertextual relations.
\end{abstract}

Key words: translation, intertextuality, cultural asymmetries, Polish literature, translation strategies

\section{For citation:}

Kaźmierczak, Marta (2019). Intertextuality as Translation Problem: Explicitness, Recognisability and the Case of "Literatures of Smaller Nations". Russian Journal of Linguistics, 23 (2), 362-382. doi: 10.22363/2312-9182-2019-23-2-362-382.

\section{Интертекстуальность как переводческая проблема: эксплицитность и узнаваемость при переводе из «литератур небольших народов»}

\author{
Марта Казьмерчак \\ Варшавский университет \\ Krakowskie Przedmieście 26/28, Варшава, 00-927, Польша
}

\begin{abstract}
Аннотация
Статья посвящена вопросу передачи интертекстуальных сигналов в художественной литературе, а особенно при переводе польской поэзии на английский язык. Выбор материала обусловлен задачей изучения интертекстуальных текстов в литературах, которые не являются широко извест-
\end{abstract}


ными, что создает, по мнению автора, особые трудности при переводе. Цель данной статьи исследовать два фактора, влияющие на трудности перевода: уровень эксплицитности (явности) межтекстовой связи и узнаваемость архетекста, а также их взаимоотношение. В начале представлены именно эти условия, которые способствуют успешной передаче интертекстуальности. Данные установки затем подвергаются предварительной проверке. Затем на основе нескольких стихотворных отрывков и их переводов автор показывает, как уровень явности влияет на переводческие решения и как, в свою очередь, примененные в переводе процедуры эксплицитации и имплицитации влияют на интерпретационный потенциал текстов. Приведены также примеры успешного преодоления объективных трудностей при передаче интертекстов. Автор утверждает, что даже маркер, который в целевом контексте нелегко поддается интерпретации, может сработать как сигнал межтекстовой связи.

Ключевые слова: перевод, интертекстуальность, культурные асимметрии, польская литература, переводческие стратегии

\section{Для цитирования:}

Kaźmierczak, Marta. Intertextuality as Translation Problem: Explicitness, Recognisability and the Case of "Literatures of Smaller Nations" // Вестник Российского университета дружбы народов. Серия: Лингвистика $=$ Russian Journal of Linguistics. 2019. Т. 23. No 2. С. 362-382. doi: 10.22363/23129182-2019-23-2-362-382.

\section{INTRODUCTION}

The paper focuses on the issue of translation of intertextual markers in literature, with a special emphasis on Polish poetry. The material and perspective are chosen with a view to exploring source-culture references in the literatures less known internationally which, it is argued, is a sphere of particular cultural resistance to translation. I intend to survey the importance of the level of explicitness of intertextual links for the task of a translator, but also to investigate recognisability — the other crucial factor — as well the interrelation of the two.

The paper is organised as follows. In the following section theoretical assumptions are laid down, explaining the two factors that form the methodological grid to be tested in the further investigation. Section 3 brings forth two cases in which the openness of reference and relatively high recognisability are checked as conditions possibly facilitating the intercultural transfer in a more general context. This forms the background to section 4, in which several examples of renditions from Polish to English specifically illustrate the situation of translating intertextually charged works from a peripheral literature. This main part of the study will be structured according to the solutions applied to intertextual markers in translations: from eliminating thereof, through implicitation contrasted with explicitation, to the instances of the resistance being successfully overcome.

Resistance is understood here as a certain barrier of untranslatability. That an original inherently defies translation in some respects, which must be overcome, is an essential feature of intercultural mediation, exemplified in countless studies. Let me only mention that in a philosophical framework it was stressed e.g. by Paul Ricoeur (2006: 30 - 39). Interest in the cultural dimension of the text as the source of translation difficulties is strongly present in the thought of Olgierd Wojtasiewicz, whose views form part of the methodological framework formulated here (see section 2). The word "resistance" 
is not used by me in any political sense, I therefore consciously refrain from mapping this notion on ideologically loaded concepts ${ }^{1}$.

Key notions as they are construed here will be explained as the paper develops, i.e. there, where they become necessary for the argumentation: intertextuality, explicitness, recognisability - in the section below, literature of the smaller nations - in the opening of section 4 .

\section{THEORETICAL BACKGROUND}

\subsection{The notion of intertextuality}

The notion of intertextuality has its origins in literary studies: Julia Kristeva derived it from Mikhail Bakhtin's claim that a literary text is not only a dialogue between the author and the reader but also a dialogue with the whole of the contemporary, the previous and the future culture (Kristeva 1969: 143-173). Thus, intertextuality implies a dialogue and connections of a text with another text, other texts or types of texts which is effected by means of quotations, allusions, by borrowing structure, etc. When broadly understood, intertextuality covers three types of relations: text - text, text genre, and text - reality. At the same time, many scholars postulate limiting the meaning of the term to just one or two of the types of relations. There are numerous classifications of intertextual phenomena, yet, for space limitations I will not go into the nuances of typologies by, among others, Laurent Jenny (1976), Gérard Genette (1982), or Ryszard Nycz (2000: 79-109).

In the present paper, intertextuality is understood as a relation of a given text with another text, a group of texts, or with texts of culture that precede it in time. A functional criterion is used for pinpointing the phenomenon under discussion: when a link with another text significantly contributes to a poem's semantics or is necessary for the understanding of it, it is treated as an intertextual relation. Considering that particular scholars apply very different terminology, it seems opportune to explain how the works coming into an interaction will be labelled in this study. The elements which refer to some previous texts are called intertextual signals or markers, for short - intertexts. The texts that are being referred to are called archetexts or pre-texts (the former descriptor appears for instance in Jenny [1976] and Nycz [2000], the latter is systematically used by Bolecki [1991] and in translational context by Majkiewicz [2008], whose classification is cited in the next subsection as part of my methodological framework).

\subsection{Theoretical assumptions:}

\section{explicitness, recognisability and the process of translation}

The first question to be asked in the present paper is what general conditions have bearing on the success of translation of intertextual markers. The translator's work with an intertext consists of two phases: first, noticing the link with some previous text and localizing the source of reference and second, re-creating it in the target text. The two

${ }^{1}$ For resistance in postcolonial context see Wang Hui (2009: 202-203), who, incidentally, also tackles translating between dominating and dominated cultures (2009: 201-202). 
stages can be correlated with two factors that facilitate or hinder the transfer of intertextuality: the degree of openness of reference in the original text and the potential recognisability of the marker in the target culture (see Table 1).

Table 1

Stages in translating intertextual markers

\begin{tabular}{|c|l|l|}
\hline & \multicolumn{1}{|c|}{ stage of translator's work with an intertext } & \multicolumn{1}{c|}{ factors defining the difficulty of translation } \\
\hline 1 & $\begin{array}{l}\text { noticing the intertextual marker, determining its } \\
\text { source and significance for the receiving text }\end{array}$ & level of openness of reference \\
\hline 2 & $\begin{array}{l}\text { re-creating the intertext in the target text, } \\
\text { so as to accommodate its function }\end{array}$ & $\begin{array}{l}\text { (range of) recognisability of the archetext } \\
\text { or of the allusion }\end{array}$ \\
\hline
\end{tabular}

Thus, from a theoretical perspective, explicitness should facilitate the transfer of intertextuality, since it makes the first stage easier. To the contrary, a hidden reference may be overlooked by a translator and as a result - may not be reproduced adequately in the target text. As Ritva Leppihalme has observed, especially novice translators may have problems with identifying the very presence of allusions in the source text (1997: 178 - 195) while even experienced ones acknowledge that they may miss some intertextual markers (1997: 87).

One of translation scholars to attach high importance to the level of openness of reference is Anna Majkiewicz. Based on this criterion, she has distinguished and explored (Majkiewicz 2008) four categories of intertextual markers. The typology will be adopted in the following part of the paper.

- Thus, intertextual signals are elementary when the situation of reading or quoting is verbalised and the source is indicated or an interpretive tip is given.

- Explicit intertextuality involves an overt situation of citing but the source is not openly indicated (e.g. a quotation marked graphically but not attributed). Alluding by means of proper names also belongs to this category.

- Implicit intertextuality means that only some recurring or specifically placed elements or intended incohesion signal a dialogue with another text.

- With covert intertextual markers, the receiving text does not show in any way that there is some link; the reference remains potential (hidden quotations are an example) (Majkiewicz 2008: 23-26).

Majkiewicz postulates that whenever relevant for the original work, the net of intertextual relations should be thoroughly studied by the translator and restored in the target text. She pleads for retaining the signals, even if implicit or covert, and for embracing the exotic (foreign) quality activated this way (2008: 178 - 179). Intertexts should be made accessible to competent readers, however small that minority may be in the target-language community.

For commenting on the other line of the chart, remarks by Olgierd Wojtasiewicz will be useful. A decade before Kristeva introduced the term "intertextuality," Wojtasiewicz pondered (1957: 76-89) the problems in translating works which contain references to other texts and to non-literary facts. He called such elements "erudite allusions" and extended the traditional concept of allusion so as to include references to literature, to other arts, to historical facts and potentially — to any extratextual 
phenomena (1957: 77). Thus, he made it as capacious as the notion of intertextuality is in modern understanding. He found allusions one of the central translational difficulties.

Since in his theory translation in general is defined as producing texts which raise similar associations (1957: 27), the same criterion is applied to rendering allusions. Wojtasiewicz classifies them according to the level of translatability and underscores that "each allusion evokes the associations intended by the author only in those readers who understand it" (1957: 77, transl. mine). Since with allusions there is normally a greater risk of incomprehension on the part of a secondary recipient than on the part of a primary one, many allusions will of necessity fall into the category of untranslatable ones. As can be seen, what Wojtasiewicz treats as the decisive element is the target recognisability, construed as a field of resistance to translation ${ }^{2}$.

To rephrase and expand Wojtasiewicz's observations, the success of the stage of re-creation of an intertextual marker in translation depends on the level of diffusion of its archetext in world culture, or, pragmatically speaking — on its recognisability in the given target culture. Thus, for a (direct) translation of an intertext to work, i.e. to evoke approximately the same associations, the following is needed:

- a translation of the archetext should exist in the target culture (in certain cases an idea about the pre-text suffices: if a cursory reference is made by means of a title, a customary target version of the title of a yet untranslated work will be enough);

- the existing translation of the archetext must be used when translating the source text (the standard target version of a painting's title, etc.);

- in the event of multiple target versions of the archetext, the canonical or the one most familiar to the audience promises optimal results;

- it must resonate with the target readers (one could ask if it is at all feasible).

On the basis of the above it can be assumed that both the level of explicitness in the source text and the recognisability of the marker from the point of view of the target recipient may exert a significant influence on the shape and quality of a rendition. The operation and possible interrelation of the two factors needs verifying on empirical examples.

\section{VERIFYING THE THEORETICAL ASSUMPTIONS}

In the discussion of the two cases in this section, the openness of reference and relatively high recognisability will be checked as factors possibly facilitating the intercultural transfer in a more general context. The first illustration is a fragment from George MacDonald's novel The Baron's Apprenticeship (There and Back) ${ }^{3}$ and its

${ }^{2}$ It is natural that he should abstract himself from the possible difficulties encountered on the first stage of work with intertextual material, since he was building a general theory and consequently adopted the concept of an "ideal translator" (cf. Wojtasiewicz 1957: 8).

3 The English passage is quoted from the edition which is indicated in the translation as its source text. The novel in its original form, titled There and Back, is much longer (3 volumes) and overtly attributes The Rime... to Coleridge (cf. MacDonald 1891 [on-line], Ch. 22). The revised Baron's Apprenticeship substantially reduces ruminations on philosophy and literature and the attribution goes with them. The Polish translation follows the revised version in text reductions. 
Polish translation. The reference is, in Majkiewicz's typology, elementary - the characters are discussing a poem whose title is stated:

"Did you ever notice, in The Rime of the Ancient Mariner, the point at which the dead bird falls from the neck of the man?"

"I don't even know what you are talking of," answered Barbara. "Do tell me. It sounds like something wonderful! Is it a story?"

"Yes - a wonderful story"

He began to repeat as much of the ballad as he could, and went on, never slackening his work. The very first stanza took hold of Barbara.

(MacDonald 1986: 74).

- Czy zwróciła panienka uwagę na ten moment w „Rymowance starego żeglarza”4, kiedy martwy ptak spada z szyi człowieka?

- Nawet nie wiem o czym pan mówi - odparła Barbara. - To brzmi cudownie! Czy to opowiadanie?

- Tak, wspaniałe opowiadanie.

Powtórzył z ballady tyle, ile pamiętał, nie zwalniając tempa pracy. Już pierwsza zwrotka zachwyciła Barbarę.

(MacDonald 1995: 86).

["Have you, miss, paid attention to that moment in 'The old sailor's rhyme' when the dead bird falls from the man's neck?"

"I don't even know what you are talking of," answered Barbara. "It sounds wonderful! Is it a short story?"

"Yes, a wonderful short story."

He repeated from the ballad as much as he remembered, never slackening his work. Already the first stanza delighted Barbara.

(Back-translation - M.K.)]

The openness of reference is an undisputable advantage for the translation, and it is this that enhances the possible recognisability in the target context. Coleridge's poem may not be as well known in Poland as it is in the source culture, but it had undergone two translations before this rendition of MacDonald was undertaken: Pieśn o starym żeglarzu, by Jan Kasprowicz (Coleridge 1907/1971), and Rymy o sędziwym marynarzu by Stanisław Kryński (Coleridge 1963). Referring to any of the two would have enabled the readers to identify the archetext, even if it remained unattributed in the Polish version of the novel (while the identification would have been more difficult with an unattributed quotation).

However, the translator of The Baron's Apprenticeship, Jolanta Bartosik, does not take any of the two versions of the title into account and offers her own rendition. It is against the general rule effective in Poland which advocates deploying an existing translation unless some special circumstances preclude it. Moreover, Bartosik's "own translation" is far from accurate. First of all, the function of the preposition of has been interpreted as the possessive one and, as a result, the Ancient Mariner is no longer the personage of the rime, but the one whose it is, i.e. who says it or has authored it. (He does tell his tale to the wedding guest, but if the target-language grammar cannot

4 Throughout the paper all the emphases in the quotations added for the sake of argumentation $-M . K$. 
convey the two meanings at a time it is more sensible to choose the locative case, as Kasprowicz and Kryński did: o żeglarzu, o marynarzu — 'about the mariner'). And what does he supposedly recite? - In Polish rymowanka means a nursery rhyme or a doggerel, stylistically quite opposite to rime, elevated as the latter is by archaic spelling. Rymowanka is thus not suggestive of anything "wonderful," as Barbara expects. The generic information is further distorted: MacDonald's characters refer to The Rime of the Ancient Mariner as a "story" because it is a "narration of a chain of events" (cf. Anderson et al. 2004), but it is told in verse, whereas the Polish noun opowiadanie indicates the genre of short story and distinctively connotes prose. However, the sentences following in the translation inform that the work in question is a ballad (ballada) and that it is divided into stanzas (zwrotka). The translator, although seemingly closely following the original, flaunts inconsistencies. Having disregarded the elementary (overt) intertextual signal, she nonchalantly misrepresents Coleridge's poem as far as identification, generic characteristics and - indirectly - level of artistry are concerned. When you add the image of a "dead bird on the neck" - possibly ridiculous for those who do not know The Rime - the Polish readers will wonder why the two characters enthuse over some kitschy doggerel. In turn, the recipients competent enough to recognise the intertextuality despite the distortion may suspect parodic intentions in MacDonald's use of it, which is not the case.

The second example, Czesław Miłosz's (1911-2004) poem "Tak mało" ("So little"), allows one to explore the issue in much different circumstances. The openness of references in the source text is lower, the signals range from implicit to covert. What is also changed is the opposite direction of translation, from Polish into English, while the Russian rendition is added to verify whether the results depend on the particular target language or not $^{5}$.

\begin{tabular}{|c|c|c|}
\hline Cz. Miłosz, "Tak mało" & $\begin{array}{c}\text { "So little," transl. Cz. Miłosz, } \\
\text { Lillian Vallee }\end{array}$ & $\begin{array}{c}\text { “Так мало,” } \\
\text { transl. Andrei Bazilevsky }\end{array}$ \\
\hline $\begin{array}{l}\text { Tak mało powiedziałem. } \\
\text { Krótkie dni. [...] } \\
\text { Paszcza lewiatana } \\
\text { Zamykała się na mnie. } \\
\text { Nagi leżałem na brzegach } \\
\text { Bezludnych wysp. } \\
\text { Porwał mnie w otchłań ze sobą } \\
\text { Biały wieloryb świata. } \\
\text { I teraz nie wiem } \\
\text { Co było prawdziwe. } \\
\text { Berkeley, 1969 } \\
\text { (Miłosz 1996: 228) }\end{array}$ & $\begin{array}{l}\text { I said so little. } \\
\text { Days were short. [...] } \\
\text { The jaws of Leviathan } \\
\text { Were closing upon me. } \\
\text { Naked, I lay on the shores } \\
\text { Of desert islands. } \\
\text { The white whale of the world } \\
\text { Hauled me down to its pit. } \\
\text { And now I don't know } \\
\text { What in all that was real. } \\
\text { Berkeley, 1969 } \\
\text { (Miłosz 1996: 229) }\end{array}$ & $\begin{array}{l}\text { Как мало я успел сказать. } \\
\text { Как мало. [...] } \\
\text { Пасть левиафана } \\
\text { Сомкнулась надо мной. } \\
\text { Нагой, я был брошен } \\
\text { На необитаемом острове. } \\
\text { Белый кит } \\
\text { Швырнул меня в бездну мира. } \\
\text { Я так и не знаю, } \\
\text { Что было со мной } \\
\text { На самом деле. } \\
\text { (Милош [Mіlosh] 1993: 139) }\end{array}$ \\
\hline
\end{tabular}

5 The English rendition is almost a literal one, therefore I do not offer a philological translation of the original poem. The Russian version introduces slight differences which either are negligible in all respects or do not influence the intertextual reading: "How little have I managed to say. / How little. [...] / The jaws of leviathan / closed over me. / Naked, I was cast / on a desert island. / White whale / hurled me into the abyss of the world. / I don't [emphatic] know / what has happened to me / actually" (transl. mine - M.K., date omission - A.B.). 
This time it is the range of recognisability of the archetexts that has facilitated the transfer both into English and into Russian. Importantly, the adjective "white" (biaty wieloryb - white whale - бельй кит [belyi kit]) has not been discarded, so that the target texts are not flattened into logic but retain the interlacing of two layers of reference: the biblical and the Melvillean. True, there are shifts: pit in the English version is the biblical "pit of hell" and cannot at the same time be the ocean's deep, whereas in Polish the ambiguity of the noun otchtan' unites the two images; Andrei Bazilevsky, in turn, shifts the complement "of the world" (italicised in the table) from the whale to the abyss: "a/the white whale hurled me into the abyss of the world". Nonetheless, the intricacy of the intertextual tissue of the poem is successfully conveyed in both cases. Furthermore, the legibility of markers sensitises the target audiences to the possible allusiveness of "desert islands", and again the intertextuality is retained in English as well as in Russian. Intertextual potential can be actualised in the foreign reception although no special explication methods have been applied by the translators.

In this provisional check, the first example has shown that what is theoretically postulated as an opportune situation for translating an intertext does not necessarily correlate with a fine actual rendition. The translator has not taken advantage of little cultural resistance and her choices negatively affected the recognisability of the signal, producing a puzzling and therefore resistant textual element. In the second example, however, despite the fact that the references are neither overt by themselves nor made more explicit by the translators, the intertextuality has indeed been communicated to the target audiences. This can be ascribed to the international dissemination of the archetexts evoked: the Bible, Moby Dick (popularised by films and other intermedial adaptations), or texts of culture perpetuating the desert island topos. Furthermore, the two aspects under discussion - the level of explicitness and recognisability - appear in a close interrelation. It is evident that openness of reference is a factor important not only on the left (source) side of the translational equation.

\section{TRANSLATING "THE LITERATURES OF SMALLER NATIONS": EXPLICITNESS AND RECOGNISABILITY}

The second example has brought us to the sphere on which I intend to focus: Polish into English poetry translation. Polish literature is very much dialogical, yet it is immensely difficult to convey this quality in translation. And it is not because the renditions of the archetexts do not exist and there is nothing to establish links with (this prerequisite is often satisfied), but because the references do not resonate for the readers.

Translating from Polish frequently means an attempt at transfer from a weaker to a stronger polysystem, or to a polysystem less inviting, less welcoming towards foreign works. As Itamar Even-Zohar puts it, whether we like it or not, the "peripheral literatures in the Western Hemisphere tend more often than not to be identical with the literatures of smaller nations" (1978/2000: 194). Consequently, such is also the position of the Polish literature in relation to, for instance, the Anglophone literary system.

The inequality pinpointed by Even-Zohar becomes especially visible and painful in translating intertextual markers. As long as a reference is made to a source or motif which comes from the potential target culture or is more universally known, its successful 
translation is possible — as has been illustrated by Miłosz's poem in the previous section. However, it is very different with the allusions to the source culture if this culture is little known internationally. Obviously, the Polish culture and history are much less known in the English-speaking world than the Anglo-Saxon culture is in Poland. Therefore allusions to the Polish heritage will necessarily seem quite hermetic to the foreign audience.

Let me note that the hierarchy of interacting polysystems also affects directionality of translation. For a peripheral culture it is much more difficult to find a translator to work into the mother tongue and this necessitates either indirect (poeticising from a crib) or inverse translation (the latter term from: Beeby Lonsday 1998: 63-67). If Polish literature is to be promoted in world cultures, the task very often falls to a Polish translator or a tandem of a direct and an inverse translator. Such a situation apparently has one asset as regards rendering intertextuality: references to the source culture should be easier to notice for inverse translators and the possibly low level of explicitness will not be a hindrance ${ }^{6}$. This is, of course, small comfort if a complete lack of recognisability prevents the conveyance of an allusion or makes a whole text puzzling for the target readers.

Does it mean that translators must just resign themselves to this? Wojtasiewicz has emphasised that many allusions cannot in fact be "translated", they can only (but still!) be explained. Therefore he defines the task of the translator as levelling the "differences in erudition" between the original author and the secondary recipient (1957: 77-79). This implies and justifies explication on the part of the translators. As shown above, explicitness of markers and recognisability tend to dovetail, and this suggests that raising the level of openness of an allusion under translation may be a way to improve its recognisability for the target audience. Among the types of explicitation described in translation studies, such a move for the sake of preserving intertextuality would therefore functionally correspond to pragmatic explicitation (cf. Klaudy 2009: 106-107).

Several more examples taken from Polish poems containing references to Polish literature, art and history will serve as further illustrations. The native culture is by no means the only domain of reference in the Polish literature, but I choose to concentrate on specifically such intertexts since they seem to be prototypical for the problems connected with translating into a stronger polysystem.

\subsection{Elimination (of texts and intertexts)}

Before proceeding to examples of translational explicitation and implicitation, a reservation is necessary. High cultural resistance may lead to eliminating intertextuality - by leaving some texts untranslated, by removing intertextual markers or by obliterating the signals retained.

Faced with the "imbalance of power" between the cultures from which and into which they are working, translators may feel powerless and simply renounce the trans-

${ }^{6}$ This assumption will not always be confirmed in practice, especially if the Poles undertaking the translation are amateurs in the literary field (notably Jan Langer, who rendered into English Leśsmian and Tuwim, appears completely unaware of intertextuality, cf. Kaźmierczak 2012: 237). 
lation of works with pronounced dialogical qualities. Admittedly, if an entire text (e.g. a parody) fundamentally relies on a pre-text, then either the relation should be obligatorily re-created or the translation project given up altogether.

However, results of a study based on the works of the Polish modernist Bolesław Leśmian (1877-1937) and their translations suggest that also explicit (not necessarily holistic) intertextuality daunts the translators (Kaźmierczak 2012: 43-52). Poems in which the use of quotations is openly marked have not been translated into English at all, and tend to be rendered less often, and later than others, into Russian. Moreover, in certain Russian versions the translators eliminated explicit intertexts altogether or removed from them the distinguishing graphic marks. On the one hand, Leśmian, combining linguistic experimentation with a strict metrical and musical organisation of verse, is notoriously difficult to translate. Thus, the selection of poems may have been oriented on evading an additional difficulty. On the other hand, removing the quotes, i.e. a purposeful and radical reduction of the openness of reference (from elementary to covert), might indicate unwillingness to mark for the target readers an intertextual relation that does not exist in their language.

\subsection{Implicitation vs. explicitation}

Yet the openness and obligatory character of intertextuality do not always lead to a non-selection and the translators attempt to overcome the resistance, or to go around it. Such attempts can be illustrated on the example of Bolesław Leśmian's 1936 ballad "Urszula Kochanowska", as rendered into English with the use of two opposite strategies as regards intertexts.

Urszula or, in Renaissance Polish, Orszula, was the daughter whose death in infancy Jan Kochanowski mourned in his cycle Treny (Threnodies/Laments), one of the early masterpieces of Polish literature, first printed in 1580. Leśmian's poem is in its entirety referential with respect to Kochanowski's Threnodies (connected with "Threnody XIX" on the level of the plot) and for the source-culture recipients, even of limited erudition, the link is evident. It relies on the following markers: the protagonist's name and surname, the toponym Czarnolas and the derivative adjective czarnolaski, as well as the lyrical situation (reversed: Urszula, although staying in heaven, misses her parents).

Kochanowski's Threnodies have enjoyed popularity with translators and there are six English versions of the archetext ${ }^{7}$. Of them only the conjoined work of Seamus Heaney and Stanisław Barańczak (Kochanowski 1995a) has earned a greater renown, thanks to the fame of the Irish Nobel-Prize winner. Still, the work cannot be said to have become an integral part of an Anglo-Saxon reader's cultural encyclopaedia. As a result, the level of recognisability of Leśmian's intertextual dialogue will inevitably plummet under translation, which in turn may prompt intervention on the part of the translators. In this context it is interesting to trace the evolution of one of the English renditions of "Urszula Kochanowska".

7 The list of the renditions is as follows: Laments - transl. Dorothea Prall Radin, 1920, 1928; Laments - transl. S. Heaney, S. Barańczak, 1995; Laments - transl. M. J. Mikos, 1995; Treny transl. Adam Czerniawski, 1996; Threnodies - transl. Barry Keane, 2001; Threnodies - transl. Leonard Kress, [n.d.]. 
The possible forms of the name and surname of the heroine of Leśmian's ballad are an issue in themselves (cf. Kaźmierczak 2012: 180 - 183), but since both versions to be discussed in this subsection are entitled "Ursula Kochanowska", let me not dwell on it here. I propose to concentrate on another intertextual signal: the name of her house. Czarnolas is the estate where Kochanowski spent the most fruitful years of his life and literary career and which he mentions in his works on numerous occasions. In the Polish culture the toponym has become inextricably bound with the poet, often called simply "Jan of Czarnolas"; it is also eponymous for a place where poetry has its source, as evidenced e.g. by Julian Tuwim's 1928 poem "Rzecz Czarnoleska" (cf. Tuwim 1968: 34 for English translation). Czesław Miłosz explains to the Western reader in his History of Polish Literature: "Since his [Kochanowski's] mature and best works were written there, the name 'Czarnolas', which means 'Blackwood', has unique legendary connotations for Polish poets" (Miłosz 1969/1983: 61).

The following fragments of Leśmian's ballad will be relevant for my discussion:

Gdy po śmierci w niebiosów przybyłam pustkowie,

Bóg długo patrzał na mnie i głaskał po głowie.

„Zbliż się do mnie, Urszulo! Poglądasz jak żywa...

Zrobię dla cię, co zechcesz, byś była szczęśliwa”.

„Zrób tak, Boże — szepnęłam — by w nieb Twoich krasie

Wszystko było tak samo, jak tam — w Czarnolasie!” — [...]

Uśmiechnął się i skinął - i wnet z Bożej łaski

Powstał dom kubek w kubek jak nasz - Czarnolaski.

(Leśmian 2000: 383, 11. 1-6, 9-10)

The first version of the translation was the result of a workshop held in 2002 as part of the IV Lublin Translation Conference, under the guidance of Michael J. Mikos and Richard Sokoloski (Leśmian 2003: 18, 20). The extract corresponding to the one above shows that both the place name in the locative case, $w$ Czarnolasie ('in Czarnolas'), and the adjective czarnolaski (in the phrase 'our Czarnolas house') have been replaced with periphrases: "our house of old", "our earthly place":

When I reached heavens, so bare, after I was dead,

God looked at me for a long time and stroked my head.

"Come closer to me, Ursula! How keen is your gaze...

I will grant you any wish to see joy on your face!"

"Make it God", I whispered, "in your splendors untold, That all be the same as in our house of old". [...]

He smiled, giving a sign, and 'twas then by God's grace A house arose, board for board like our earthly place.

(Leśmian 2003: 18)

The only intertextual signals which remain in the translation are the title - "Ursula Kochanowska", and the name repeated as an address. One could argue that the protagonist's name is the more important marker and that retaining it helps establish an unequivocal relation with the pre-text. However, for an English-speaking recipient the surname 
"Kochanowska", if not supported otherwise, may prove an empty sound. The name of the family estate, especially a foreign one, would sensitise the reader to the fact that a specific localisation may constitute an allusion to personages or facts which are authentic and/or inscribed in the collective consciousness of primary recipients. I would argue that even an illegible (not readily decipherable) marker would then be a signal of intertextuality.

The authors of the collective translation do not help the cognition of the target reader by adding any external or inserted clue. On the contrary, they have deleted one of the referential elements, thus further decreasing the level of explicitness. Perhaps the intended result was to make the message more universal; however, it is intertextuality that is the essence of Leśmian's poem, whereas implicitation has affected recognisability. In the translation Ursula is no longer the daughter of Jan of Czarnolas, mourned in the Threnodies; she becomes an unspecified person who has died and is waiting in heaven. She is a girl - if the recipient deduces her young age from the fact that it is usually children that are stroked on their heads (cf. the first couplet). Her age, however, if not her specific identity, is crucial for the understanding of the creation of this persona. By making Ursula the speaker in the poem, Leśmian introduces a naïve discourse and the mentality of a child, who treats God as a magician. This serves subverting the message of the archetext: death does not protect from orphanhood, as Kochanowski is assured in "Threnody XIX", the last in his cycle (cf. 1995a: 73, 75) — in the 1936 ballad Ursula misses her parents and heaven is described as desolation, which is ultimately a polemic with the Christian outlook of the Renaissance poet.

The reduction of intertextual markers may have resulted from the artificial situation of translation (during a workshop) and from the compromises entailed in making collective decisions. Moreover, the rendition did not have a specific recipient - whereas it is the projection of the reader, of his/her cultural competence and needs, that shapes the translation strategy, even more so with respect to intertextual elements.

Thus, a changed context and a particular projection of the recipient may thoroughly re-shape the treatment of intertextuality. M.J. Mikos published a much modified version of this translation in the fifth part of his anthology of Polish literature aimed at American readers, especially for Polish studies (Leśmian 2006: 300). While dependence on the previous variant is visible, essential changes include the introduction of the name "Black Forest":

"Come closer, Ursula! How lively is your gaze...

I'll do what you wish for to bring joy to your face."

"Make it, God - I whispered — in Your heaven's splendid nest,

Exactly the same as there - in the Black Forest!" [...]

He smiled and gave a sign - and soon by God's behest

A house rose - board for board, as ours - in the Black Forest.

Academic character of the translation is underscored by an extended note that accompanies the text:

Jan Kochanowski (1530 - 1584) settled in his hereditary estate of Czarnolas (Black Forest). The name became the symbol of early Polish poetry. Kochanowski's Laments, written after the death of his beloved daughter Ursula, especially lines 31-44 of Lament 
XIX or The Dream, set the stage for Leśmian's poem (see my Polish Renaissance Literature. An Anthology. Columbus: Slavica, 1995, 204-205).

The note explains all the intertextual elements, and even points to the pre-text in its specific English version, whose authorship promises the existence of an interrelation. Also the toponym Black Forest receives a justification. Nonetheless, the anglicisation seems a curious decision, in view of the fact that the name of the estate is not a telling one and that his earlier anthology, the book to which Mikos refers his readers, contains an epigram entitled in English "On my House at Czarnolas" (Kochanowski 1995b: 163). If the change was motivated by the search for a rhyme, the effect is not fortunate - the rhyme demands misplacing the word-stress and sounds forced. Moreover, a transferred foreign name would have been a stronger (a more explicit) intertextual marker than a naturalised, semantically transparent one.

As regards the deployment of a note, it is the academic context of translation that fully justifies this solution. Although, as Galina Denisova's findings show, footnotes may relatively frequently serve to mark and elucidate intertextuality in the renditions of prose works (Денисова [Denisova] 2003: 218-258), in general it is a means of explicitation of limited applicability and not particularly suitable for poetry. Furthermore, there is the publishers' reluctance to include paratexts in translated books, accounted for by economic considerations and partly by the readers' (real or alleged) prejudice. Nonetheless, when transferring peripheral literatures into stronger polysystems, paratextual methods of explication seem to a greater degree valid, in some situations even indispensable.

\subsection{Overcoming the resistance}

Implicitation may lead to functional obliteration of intertextuality, while making intertextuality overt (elementary) by means of an added paratext will often be an inappropriate solution or a too radical one. Between the two poles there are, obviously, other techniques of varied usability depending on the context: in-text explanation, modification, substitution. Certain judicious interventions will be illustrated on three more examples.

One of Tadeusz Różewicz's (1921-2014) formally and intellectually austere poems brings a disturbing vision of a whole world furnished with doors, not leading anywhere but rather enclosing the subject (cf. Pieszczachowicz 1991: 263):

\begin{tabular}{|l|l|}
\hline \multicolumn{1}{|c|}{ T. Różewicz, *** (Drzwi w ścianach domów) } & “Doors in walls of houses...", transl. A. Czerniawski \\
\hline Drzwi w ścianach domów & $\begin{array}{l}\text { Doors in walls of houses } \\
\text { doors to kitchens doors to bedrooms [...] }\end{array}$ \\
drzwi do kuchni drzwi do sypialni [...] & $\begin{array}{l}\text { one day } \\
\text { I saw a door }\end{array}$ \\
zewnego dnia & in a forest \\
w lesie & beneath the door an ant-hill \\
pod drzwiami mrowisko & a door in a garden \\
drzwi w ogrodzie & a door in a country lane \\
drzwi na polnej drodze & beyond the door a hare \\
za drzwiami zając & a museum door \\
drzwi w muzeum & behind the door \\
za drzwiami & "Stefan Batory at Pskov" \\
Batory pod Pskowem & [...] \\
[...] & (Różewicz 1991: 209) \\
(Różewicz 1998: 163) &
\end{tabular}


It is the last of the cited lines that is of intertextual quality, a reference to Jan Matejko's monumental historical painting. In English, Adam Czerniawski has not limited himself to reproducing the line as it was: Batory at Pskov would have been too hazy an allusion for a reader for whom both proper names may perhaps have no clear referents. The translator's intervention entails, first of all, marking the phrase as a preformed one by means of quotation marks. Admittedly, what you can expect to see behind a museum door are works of art, but the unexpectedness of entrances found everywhere by the lyrical subject may derail the recipients from a "realistic" reading. Despite his programmatic rejection of punctuation, inverted commas are the only mark employed by Różewicz with any frequency, hence introducing them into a translation does not distort his poetics. Symptomatically, the poet uses the quotes to distinguish certain titles of foreign works, while he leaves the Polish ones unmarked (compare: "Wyspe umarlych" vs. Cyrk Wojtkiewicza ${ }^{8}$, Różewicz 1998: 109 and 130), therefore the translator's action only accommodates the reversed perspective of the recipients. Czerniawski's second move consists in adding the Polish king's first name, which is actually part of the painting's original full title. This heightens the probability of - at least vague recognition of the person (better known in English as Stephen Báthory) and the event (the 1581-1582 Livonian campaign of Polish-Lithuanian forces).

The result of the intervention suggests a work of art of a historical topic, which is enough for a meaningful and undisturbed reading of the poem ${ }^{9}$. Thus, the lexical and typographical additions serve as an effective compensation, redressing the balance between the cognitive resources of the primary and the secondary recipients.

The next intertext proposed for the analysis is a line by Cyprian Kamil Norwid (1821 - 1883), a "dark" writer, difficult both linguistically and philosophically. In the fifth part of his poem "Chopin's Piano" ("Fortepian Szopena"), Norwid claims that Chopin's music is the quintessence of Polishness and among the qualities that he finds in it there is:

Polska — przemienionych kołodziejów! (Norwid 1996: 331)

[lit.: "Poland - of transformed wheelwrights"; spacing in the source].

This intertextual marker opens several layers of meaning: first, it refers to the halflegendary prehistoric ruler, Piast the Wheelwright; then, in plural, "the Poland of wheelwrights" is Poland under the rule of the Piast dynasty. The transitive verb przemieniac means "to transform", "to change", but Norwid's participle przemieniony alludes to more than just a craftsman-turned-king: in the poet's vision it implies a union between the past and the modernity and also a programme of spiritual rebirth.

The intertextuality is implicit, but for the Polish reader still quite noticeable, also because strengthened by the spacing, an example of Norwid's idiosyncratic use of typo-

8 The first reference is to Arnold Böcklin's painting Die Toteninsel (Isle of the Dead), the second invokes the Polish painter Witold Wojtkiewicz and his circus-related works (1905-1907).

9 The reference is to Jan Matejko's 1872 canvas, part of the collection of the Royal Castle in Warsaw. Reproduced on the museum's website: https://kolekcja.zamek-krolewski.pl/obiekt/ kolekcja/Malarstwo/tworca/Matejko,\%20Jan\%20\%281838-1893\%29/id/ZKW_1047 [30th Aug 2018]. 
graphy and punctuation. Yet in English a direct translation entails low explicitness and no recognisability: the reader will be at a loss as to how to interpret emphasis put on a totally enigmatic phrase. The original formulation is exceptionally rich in meaning, while in a foreign-language verse translation the technique of adding information will be restricted here by the capacity of the line. Thus, the intertext seems to require some interpretive re-writing, a creative transposition in Roman Jakobson's terms (1959/2000: 118).

The three English renditions cited below are presented in a study by Agata Brajerska-Mazur (2003) but only given a cursory comment there (see also Norwid 1984 for a full-text English translation). They are as follows:

the Poland of the wheelwrights, whom god had called to greatness

(transl. M. A. Michael, [1944])

Poland - land of TRANSFIGURED WHEELRIGHTS!

(transl. Lola and Eugene Gay-Tifft, 1970)

The Poland of wheelwrights transfigured into kings!

(transl. Keith Bosley, 1984)

(qtd in: Brajerska-Mazur 2003: 39, all emphases after this source).

Symptomatically, none of the translators spells out the allusion and places Piast's name in the target text, which would definitely mean a higher degree of openness. In the case of Lola and Eugene Gay-Tifft, who just retain the marker and do not intervene, it is impossible to detect a motivation (incomprehension or reluctance to do the thinking for the readers?). There is only the result to see: the use of majuscule and the verb "to transfigure," literary and with religious connotations, do not suffice to suggest any line of interpretation. Intertextuality becomes completely hidden and only recoverable for recipients with exquisite knowledge of Polish culture (cf. Majkiewicz's views cited above).

The two other translators have attempted to bring the implicit meanings to the readers, and both chose the same strategy: explaining or suggesting the nature of the transformation. Keith Bosley's "transfiguration into kings" is the only solution to receive a word of approval from Brajerska-Mazur (2003: 39). It gives even an unknowledgeable but inquiring reader clues enough to discover Piast as the referent. Still, it is doubtful whether the philosophic programme underlying the phrase is communicated to the recipients. For instance, despite Piast being a yeoman, Norwid's idea should not be misread as a programme for Polish art to become rustic or pastoral. If one considers the risk of misinterpretation connected with taking Piast too literally, M.A. Michael's translation may win some appreciation. Vague as it is, it can still be suggestive of the founder of the first Polish dynasty, while also open to additional interpretations on other levels (although the religious element introduced may tilt the readers' associations towards sanctity or martyrdom $)^{10}$.

The Gay-Tiffts have not eliminated the marker, yet their almost literal rendition of it proves to be ineffective. The other two translations display a conscious effort to

${ }^{10}$ Admittedly, the presence of the comma is somewhat unfortunate, inasmuch as the relative clause could possibly relate to "Poland" (personified - cf. whom). 
convey the meaning despite the cultural distance. In both cases this entails making the utterance clearer, but not by a radical increase in explicitness.

For a final example let us return to Leśmian's “Urszula Kochanowska”. The author of its most recent English translation, Marian Polak-Chlabicz, gave it the title "Ursula, the Poet's Daughter" (Leśmian 2011: 121). Replacing the surname which does not reverberate for a foreign recipient with a periphrasis allows the ballad to be read meaningfully even in the absence of an explanatory paratext. Admittedly, the translation is equipped with a succinct footnote, but the shift in the title prepares it to function on its own. Indeed, in a later reprint in another collection of Leśmian's poems, the text appears without the comment $(2017: 53,55)$ and, I dare say, stands the test of isolated reading. This statement, however, should be qualified twofold. Firstly, Polak-Chlabicz's policy of preparing bilingual editions plays a part in the success of this solution. The facing page carries the Polish poem, whose original title complements the English one and provides an additional clue for an inquiring reader. Secondly, Polak-Chlabicz revises his translations and every imprint, let alone a new collection, brings changes and new solutions. It is also the case with the ballad under discussion. The 2017 edition displays a small yet significant alteration to the title: "Ursula, a Poet's Daughter". The initial use of the definite article suggests a major poet, a national poet and is therefore an appropriate signal (a Polish poet of stature who has lost a young child can relatively easily be identified). The indefinite article casts the protagonist as a daughter of an unspecified man, the reference to whose profession remains unexplained in the course of the poem. The revision thus undermines the initial creative accomplishment. This case proves how sensitive a sphere translation of intertextuality is and how significantly can minute shifts alter the interpretative potential of target texts in their receiving contexts.

Examples of substituting source-culture oriented intertextual markers with references to the target culture or a third one will not be discussed here. They may be successful as local solutions, helping to convey some quality of the source text - humorous, intellectual, pedantic (cf. Eco 2004: 151-153), etc. However, they do not testify to overcoming the resistance encountered when translating from "literatures of smaller nations", but to the contrary, mean succumbing to the power of the stronger polysystem.

\section{CONCLUSIONS}

Although intertextuality is in general a sphere of resistance to translation, the resistance is the stronger, the less the culture referred to is known internationally. In other words, the weaker its position in the global polysystem, the more difficult it is for a given culture to "export" its intertextual markers or highly dialogical texts. Intertextuality, and openness of reference, can even become a factor influencing the selection of texts for translation.

The aim of the paper has been to stress the difficulties inherent to any translation from Polish into English rather than to demonstrate spectacular achievements in overcoming the resistance. Nonetheless, I believe that a successful translation of intertexts is possible if the translator construes his role as levelling the differences in erudition between the primary and the secondary recipients, as formulated by Wojtasiewicz (1957: 77-79, see beginning of section 4 above). 
The recognisability of intertextual signals naturally changes under translation by and large decreases (unless in special circumstances which are outside the scope of the present study). This is why literal renditions of intertexts as a rule prove incommunicative. However, recognisability interlocks with the degree of openness of reference. The latter has proved important not only for the translators' interpretation of the source text, but also for the target recipients' perception. Thus, interventions enhancing the target recognisability may consist in raising the level of explicitness.

Doing so requires caution: modifications must respect the poetics of the author and the integrity of the text. An allusion spelled out is no longer an allusion and hence perhaps the unwillingness of some translators to do so. Moreover, the strategies of explicitation are dependent on the text type (e.g. prose vs. poetry) as well as on the projected reader and the context of publication.

It is worth summarising how the resistance to translation is overcome in terms of the two aspects studied in the paper. Czerniawski, by adding inverted commas in Różewicz's poem, compensates low recognisability with higher openness and takes care that the intertext does not go unnoticed as an intertext. With Norwid, however, the same level of openness is maintained: covert - covert. The translation solution cannot, then, count as explicitation, but rather explication (M.A. Michael suggests in what way the wheelwrights were transformed). In "Ursula, the Poet's Daughter" implicitation (specific surname omitted) curiously enough serves explication, which additionally relies on the co-presence of context (parallel original title) and/or an explicitation technique (note).

Anna Majkiewicz stipulates that translating texts which dialogue with other texts entails an exoticising approach (2008: 178-179). Furthermore, if recognisability naturally decreases in a target cultural context, then a translation that respects intertextuality could be expected to actively enhance explicitness (cf. Majkiewicz 2008: 306). Taken together, the two premises could suggest a correlation between explicitation and exoticisation (and the reverse, between implicitation and domestication). Interestingly, our examples in section 4 challenge such a deduction - as summarised in Table 2 below. Admittedly, eliminating markers or implicitating an intertextual relation (as happens in Leśmian's "Urszula Kochanowska” rendered by Mikos) correspond with a naturalising effect. However, Różewicz's "Batory at Pskov" would have been for an English reader equally exotic without inverted commas as it is with them, with and without the king's Christian name; the raised explicitness does not enhance the foreign flavour. In turn, "Ursula, the Poet's Daughter" may feel naturalised/neutralised as compared with "Urszula Kochanowska”, but Polak-Chlabicz's solution to Leśmian's title is in pragmatic terms more explicit for the target reader and ultimately does suggest a path to the right archetext. As for Norwid, Michael's translation to which I draw attention carries a covert marker and yet has been classified by Brajerska-Mazur (2003: 40) as an indicator of the text's strangeness/foreignness (obcość). Consequently, the surveyed material suggests that there is no straightforward mapping between explicitation/implicitation techniques and the polarised foreignisation/domestication pair of strategies. 
Mapping explicitation/implicitation on foreignisation/domestication

\begin{tabular}{|l|l|l|l|}
\hline \multicolumn{1}{|c|}{$\begin{array}{c}\text { example } \\
\text { (location in the paper) }\end{array}$} & $\begin{array}{l}\text { level of openness } \\
\text { of reference } \\
\text { in the original }\end{array}$ & $\begin{array}{c}\text { treatment of openness } \\
\text { of reference } \\
\text { in translation }\end{array}$ & \multicolumn{1}{|c|}{$\begin{array}{c}\text { the foreign quality } \\
\text { of the target text }\end{array}$} \\
\hline $\begin{array}{l}\text { non-selection } \\
\text { for translation (4.1) }\end{array}$ & $\begin{array}{l}\text { elementary, } \\
\text { explicit }\end{array}$ & (elimination) & $\begin{array}{l}\text { naturalisation } \\
\text { (of the author's oeuvre } \\
\text { in the target culture) }\end{array}$ \\
\hline $\begin{array}{l}\text { Czarnolas } \rightarrow \text { "our house", etc. } \\
\text { (4.2) }\end{array}$ & explicit & implicitation & naturalisation \\
\hline $\begin{array}{l}\text { "Stefan Batory } \\
\text { at Pskov" (4.3) }\end{array}$ & implicit & explicitation & $\begin{array}{l}\text { neutral move } \\
\text { (foreignness not due to } \\
\text { raised openness) }\end{array}$ \\
\hline $\begin{array}{l}\text { "Ursula, the Poet's } \\
\text { Daughter" (4.3) }\end{array}$ & explicit & implicitation & neutralised / naturalised \\
\hline $\begin{array}{l}\text { "wheelrights, whom god had } \\
\text { called to greatness" (4.3) }\end{array}$ & covert & $\begin{array}{l}\text { level of openness } \\
\text { preserved: covert marker }\end{array}$ & foreignization \\
\hline
\end{tabular}

Finally, if facilitating the intertextual reading turns out to be impossible or inadvisable for some reason, the minimal requirement from a translation is retaining the markers (cf. Majkiewicz 2008). Eliminating, distorting or hiding (by neutralising or by removing quotes) intertextual signals as a rule impoverishes the text under translation instead of making it more universal. On the contrary, even an illegible marker may signal the presence of an intertextual relation - after all, incohesion is a defining feature of implicit intertextuality. It should be stressed that by "illegible" I mean a marker that cannot be readily deciphered but ultimately does have a meaning, recoverable with some effort on the part of an inquiring reader. Such markers will tend to result from a strategic move of a competent and conscious translator, not from a sloppy or uncomprehending word-for-word rendition. Reluctance to do all the thinking for the readers is not the same as shifting to the recipients the whole responsibility for interpretation.

(C) Marta Kaźmierczak, 2019

\section{REFERENCES}

\section{Primary sources: texts and archetexts}

Coleridge, Samuel Taylor (1907/1971). Pieśn o starym żeglarzu [orig. The Rime of the Ancient Mariner]: Część pierwsza [Part One]. Transl. Jan Kasprowicz. In: Poeci języka angielskiego [Poets of the English language], vol. 2. Ed. Henryk Krzeczkowski, Jerzy S. Sito, Juliusz Żuławski. Warszawa: Państwowy Instytut Wydawniczy, pp. 224-226. (Originally published in: Poeci angielscy. Wybór poezyi [English poets: a selection of verse], transl. Jan Kasprowicz, Lwów: Księgarnia H. Altenberga, 1907).

Coleridge, Samuel Taylor (1963). Rymy o sędziwym marynarzu [orig. The Rime of the Ancient Mariner]. Transl. Stanisław Kryński. In: Angielscy "Poeci Jezior" [The English "Lake Poets"]: W. Wordsworth, S.T. Coleridge, R. Southey. Ed., transl. and annotated by Stanisław Kryński. Wrocław: Ossolineum, pp. 259-287.

Kochanowski, Jan (1995a). Laments [orig. Treny]. Transl. Seamus Heaney, Stanislaw Baranczak. London - Boston: Faber \& Faber. 
Kochanowski, Jan (1995b). "On my House at Czarnolas" [orig. "Na dom w Czarnolesie"] Transl. Michael J. Mikos. In: Polish Renaissance Literature. An Anthology. Ed. Michael J. Mikos. Columbus, OH: Slavica Publishers, p. 163.

Leśmian, Bolesław (2000). Poezje zebrane [Collected poems]. Ed. Aleksander Madyda. Toruń: Algo.

Leśmian, Bolesław (2003). "Ursula Kochanowska" [orig. "Urszula Kochanowska”]. Transl. collective. In: Warsztaty translatorskie / Workshop on Translation, vol. III. Ed. Richard Sokoloski, Henryk Duda, Konrad Klimkowski. Lublin — Ottawa: Tow. Naukowe KUL — Slavic Research Group University of Ottawa, pp. 18, 20.

Leśmian, Bolesław (2006). "Ursula Kochanowska" [orig. "Urszula Kochanowska"]. Transl. Michael J. Mikos. In: Polish Literature from 1864 to 1918: Realism and Young Poland. An Anthology. Ed. Michael J. Mikos. Bloomington, IN: Slavica Publishers, p. 300.

Leśmian, Bolesław (2011). "Ursula, the Poet's Daughter" [orig. "Urszula Kochanowska"]. In: B. Leśmian, 33 of the Most Beatuful Love Poems / 33 najpiękniejsze wiersze milosne, Selected and transl. Marian Polak-Chlabicz. New York: Penumbra, p. 121.

Leśmian, Bolesław (2017). "Ursula, a Poet’s Daughter" [orig. "Urszula Kochanowska"]. In: B. Leśmian, Beyond the Beyond. Poems in Polish and English. Selected and transl. Marian Polak-Chlabicz. New York: Penumbra, p. 53, 55.

MacDonald, George (1891). There and Back. Retrieved from Project Gutenberg: < http://www.gutenberg. org/files/8879/8879-h/8879-h.htm> [30 ${ }^{\text {th }}$ Aug 2018].

MacDonald, George (1986). The Baron's Apprenticeship. Ed. Michael R. Phillips. Minneapolis, MN: Bethany House.

MacDonald, George (1995). Tajemnica Sir Wiltona [orig. The Baron's Apprenticeship]. Transl. Jolanta Bartosik. Warszawa: Krzysztof Bartosik.

Miłosz, Czesław (1996). Poezje wybrane / Selected Poems. Kraków: Wydawnictwo Literackie.

Norwid, Cyprian Kamil (1984). "Chopin's Piano" [orig. "Fortepian Szopena”]. Transl. Keith Bosley. Comparative Criticism, no. 6. Ed. E. S. Schaffer, Cambridge. Reprinted at and retrieved from: $<$ http://www.brindinpress.com/ponorfor.htm> [13th Aug 2018].

Norwid, Cyprian Kamil (1996). "Fortepian Szopena.” In: Cyprian Norwid. Nowy wybór poezji [A new selection of poems]. Ed. Juliusz Wiktor Gomulicki. Warszawa: Państwowy Instytut Wydawniczy, pp. 330-333.

Różewicz, Tadeusz (1991). They Came to See a Poet: Selected Poems. Transl. Adam Czerniawski. London: Anvil Press Poetry.

Różewicz, Tadeusz (1998). Na powierzchni poematu $i$ w środku [On the surface of the poem and inside it]. Warszawa: Czytelnik.

Tuwim, Julian (1968). "The Czarnolas Matter" [orig. "Rzecz czarnoleska"]. In: "The Dancing Socrates" and Other Poems by Julian Tuwim. Selected and transl. Adam Gillon. New York: Twayne Publishers, p. 34.

Милош, Чеслав (1993). Так мало и другие стихотворения, 1934-1990. Еd. Андрей Базилевский. Москва: Вахазар. // Milosh, Cheslav (1993). Tak malo i drugie stikhotvoreniya, 1934-1990 ["So little" and other poems]. Ed. Andrei Bazilevsky. Moskva: Vakhazar.

\section{Secondary sources:}

Anderson, Sandra, et al. (eds) (2004), Collins English Dictionary. $8^{\text {th }}$ edition, Glasgow: Harper Collins.

Beeby Lonsday, Allison (1998). "Direction of Translation". In: Routledge Encyclopedia of Translation Studies. Ed. Mona Baker, Kirsten Malmkjær. London — New York: Routledge, pp. 63-67. 
Bolecki, Włodzimierz (1991). Pre-teksty i teksty. Z zagadnień związów międzytekstowych w literaturze polskiej XX wieku [Pre-texts and texts. Issues in intertextual relations in the Polish $20^{\text {th }}$-cent. literature]. Warszawa: Wydawnictwo Naukowe PWN.

Brajerska-Mazur, Agata (2003). “Trzy poziomy trudności w przekładzie z języka [polskiego] na język [angielski]" [Three levels of difficulty in translating from Polish into English]. In: Warsztaty translatorskie / Workshop on Translation, vol. III. Ed. Richard Sokoloski, Henryk Duda, Konrad Klimkowski. Lublin — Ottawa: Tow. Naukowe KUL — Slavic Research Group University of Ottawa, pp. 31-50.

Eco, Umberto (2004). Dire quasi la stessa cosa. Esperienze di traduzione. Milano: Bompiani.

Even-Zohar, Itamar (1978/2000). "The Position of Translated Literature within the Literary Polysystem”. In: The Translation Studies Reader. Ed. Lawrence Venuti. London - New York: Routledge, pp. 192-197.

Genette, Gérard (1982). Palimpsestes. La littérature au second degré. Paris: Seuil.

Jakobson, Roman (1959/2000). “On Linguistic Aspects of Translation”. In: The Translation Studies Reader. Ed. Lawrence Venuti. London — New York: Routledge, pp. 113-118.

Jenny, Laurent (1976). "La Stratégie de la forme”. Poétique 27, pp. 257-283.

Kaźmierczak, Marta (2012). Przekład w kręgu intertekstualności. Na materiale tlumaczeń poezji Bolestawa Leśmiana [Translation in the domain of intertextuality: A survey based on Bolesław Leśmian's poetry and its translations]. Warszawa: ILS UW.

Klaudy, Kinga (2009). "Explicitation”. In: Routledge Encyclopedia of Translation Studies. Second edition. Ed. Mona Baker, Gabriela Saldanha. London — New York: Routledge, pp. 104-108.

Kristeva, Julia (1969). "Le mot, le dialogue et le roman”. In: Séméiôtiké: recherches pour une sémanalyse. Paris: Edition du Seuil, pp. 143-173.

Leppihalme, Ritva (1997). Culture Bumps: An Empirical Approach to the Translation of Allusions. Clevedon - Philadelphia — Toronto - Sydney — Johannesburg: Multilingual Matters.

Majkiewicz, Anna (2008). Intertekstualność - implikacje dla teorii przekładu. Wczesna proza Elfriede Jelinek [Intertextuality - implications for translation theory. Early prose works of Elfriede Jelinek]. Warszawa: Wydawnictwo Naukowe PWN.

Miłosz, Czesław (1969/1983). The History of Polish Literature. Berkeley — Los Angeles — London: University of California Press, $2^{\text {nd }}$ ed.

Nycz, Ryszard (2000). Tekstowy świat. Poststrukturalizm i wiedza o literaturze [The world of text(s). Poststructuralism and literary studies]. Kraków: Universitas, $2^{\text {nd }}$ ed.

Pieszczachowicz, Jan (1991). Pegaz na rozdrożu. Szkice o poezji wspótczesnej [Pegasus on the crossroads: Essays on contemporary poetry]. Łódź: Wydawnictwo Łódzkie.

Ricoeur, Paul (2006). On Translation [orig. Sur la traduction, 2004]. Transl. Eileen Brennan. Introd. R. Kearney. London - New York: Routledge.

Wang, Hui (2009). "Postcolonial approaches". In: Routledge Encyclopedia of Translation Studies. Second edition. Ed. Mona Baker, Gabriela Saldanha. London - New York: Routledge, pp. 200-204.

Wojtasiewicz, Olgierd (1957). Wstep do teorii tlumaczenia [Introduction to the theory of translation]. Wrocław - Warszawa: Ossolineum.

Денисова, Галина В. (2003). В мире интертекста. Язык, память, перевод. Москва: Азбуковник // Denisova, Galina V. (2003). V mire interteksta. Yazyk, pamyat', perevod [In the world of intertext. Language, memory, translation]. Moskva: Azbukovnik. 


\section{Article history:}

Received: 10 October 2018

Revised: 18 December 2018

Accepted: 25 December 2018

\section{История статьи:}

Дата поступления в редакцию: 10 октября 2018

Дата принятия к печати: 25 декабря 2019

\section{Bionote:}

MARTA KAŹMIERCZAK is Ph.D., Assistant Professor, Institute of Applied Linguistics of the University of Warsaw. Research interests: translation and reception studies, especially cultural aspects of translation, poetry translation, intertextuality, intersemioticity, paratexts of translation.

Contact information: e-mail: mkazmierczak@uw.edu.pl

ORCID https://orcid.org/0000-0003-2925-0209.

\section{Сведения об авторе:}

МАРТА КАЗЬМЕРЧАК - кандидат филологических наук, доцент Института прикладной лингвистики Варшавского университета. Сфера научных интересов: переводоведение и межкультурная рецепция, в особенности: культурные аспекты перевода, поэтический перевод, интертекстуальность, интерсемиотические явления, паратексты перевода.

Контактная информация: e-mail: mkazmierczak@uw.edu.pl ORCID https://orcid.org/0000-0003-2925-0209. 